\title{
Special education in Poland (until 1989) - historical perspective
}

\begin{abstract}
Jacek Kulbaka, Special education in Poland (until 1989) - historical perspective. Interdisciplinary Contexts of Special Pedagogy, no. 27, Poznań 2019. Pp. 117-149. Adam Mickiewicz University Press. ISSN 2300-391X. e-ISSN 2658-283X. DOI: https:/ / doi.org/10.14746/ikps.2019.27.06

The article is dedicated to presenting the information regarding the origins, organisation and the activity of special schools and institutions in Europe, with the particular focus on Polish territories (from the beginning of the 19th century to the final years of the Polish People's Republic). The text nature may be included within the framework of inquiries regarding the history of education. Referring to the wide historical context (social, political, economical, legal, outlook and other determinants), the aim of the author of the text was to introduce the accomplishments of particular individuals, and various institutions active for the children with disabilities, in the discussed period.
\end{abstract}

KEY WORDS: The history of special education, disability

Special schooling, including the launching of the first public educational institutions, had been born in Europe during the Enlightenment period, at the turn of the $18^{\text {th }}$ and the $19^{\text {th }}$ centuries. In source literature, it is generally assumed, that special education for deaf persons, began in 1770, with the creation of schools by rev. Michel L'Epee in Paris, and German Samuel Heinicke in Leipzig, in 1778 . 
The beginnings of education for blind persons are related to Valentine Haüy, who began pedagogical work with blind children in 1784.

The education of children with intellectual disabilities, began in Europe, in the first decades of the 19th century, with one of its pioneers being Jean Gaspard Itard, who went down in history as the private teacher of the "wild boy" found in the Aveyron woods. The Report, written by Itard in 1801-1806, is a relic of his few years of work with the teenage boy, named Victor. Itard's educational achievements provided inspiration for other French scholars, i.a. Jean-Étienne Dominique Esquirol and Édouard Séguin - the founder of the first public special school in Paris, in 18371.

One should note, that the education of deaf persons, had begun earlier than it is generally assumed, starting already in the $16^{\text {th }}$ or the 17th century. The Spanish, the Dutch, and the English, often independently, successfully taught speech and fingerspelling to deafmute persons. Among them were, i.a. Geronimo Cardano, Pedro Ponce de León, Juan Pablo Bonet, Manuel Ramirez de Carrión, and in the following centuries $\left(17^{\text {th }}-18^{\text {th }}\right)$ by Konrad Amman, Jan Baptist van Helmont, John Wallis, et. al. ${ }^{2}$ Working in recession, many of them, scientists, physicians, and ordinary people of passion, wouldn't want to, or did not take enough effort, to record their own pedagogical achievements for future generations.

The fact that the first public schools and special institutions (with boarding) for the death, the blind, and for persons with intellectual disabilities, had emerged at the end of the Enlightenment period, was a result of many factors. One of them, was the myth from the ancient times, related to the views of Plato and Aristotle, and universally rooted in people's minds, about the ineducability of this category of persons. In the thousand-year medieval period,

1 B. Szczepankowski, Niestyszący - Gtusi - Gtuchoniemi, Warszawa 1999.

2 K. Kirejczyk, Ewolucja systemów dzieci głuchych, Warszawa 1967; E. Nurowski, Surdopedagogika polska. Zarys historyczny, Warszawa 1983; A. Manczarski, Historia nauczania głuchoniemych, „Nauczyciel Głuchoniemych i Ociemniałych”, no 2-3, 1934. 
a small progress was accomplished, as a result of the views of St. Augustine, and St. Thomas Aquinas. The Church displayed itself as an institution taking care of the matters of education, and social care. Persons in need of aid, were given direct help by private benefactors and the so-called hospitals that served as a refuge, also referred to as asylums or hospices. The activities for the needy, were based on the idea of mercy and would bear all the symptoms of charity activity. Since the modern period - in result of the divisions in a, previously, rather hermetic Christian world - secular and self-government factors had begun to involve themselves in the care activities, particularly, where the congregation adopted the teachings of Martin Luther, John Calvin, Huldrych Zwingli, and other figures of the religious Reformation. In the $17^{\text {th }}$ century, the tasks of the social care were taken over by the increasingly bold state institutions, that would coordinate, and support the charity activities from the top-down perspective (France, Austria). In Catholic states, including i.a. Poland, the Church would still remain the administrator of hospital care, until the end of the First Polish Republic. The attempts, made by king Stanisław August Poniatowski, to assume state control over the care activities, were unsuccessful. Stanisław Leszczyński's and Stanisław August Poniatowski's personal concern regarding the education of deaf-mute persons, found no followers.

The Rev. Jakub Falkowski Deaf-Mute Institute (Instytut Głuchoniemych księdza Jakuba Falkowskiego), began its activity at the end of 1817 in Warsaw, and it was the first special school in Poland. The education of blind children (since 1842) was almost 50 years late in comparison to the Paris Institute (1784). Similar with the organisation of the education of children with intellectual disabilities, which had begun only at the turn of the 19th century in Poznan. In terms of resocialisation, the Polish thought and practice would follow the European trend, as can be seen from the contents of the Kodeks project of Andrzej Zamoyski from the 1880s, as well as the pedagogical and organisational activity of Fryderyk Skarbek and Stanisław Jachowicz in the Kingdom of Poland, in the first half of 
the 19th century. One should highlight that persons with disabilities were mostly treated humanely. It is evident from the records of the medieval Magdeburg Rights, the Casimir III the Great codices, and the statutes of John I Albert and Sigismund I the Old, from the 15 and the $16^{\text {th }}$ centuries ${ }^{3}$.

Instead of the theories of the Enlightenment (empiricism and rationalism), it was the civilisational transformations started in the period, and related to the development of natural sciences, particularly medicine, that were breakthrough for special education. For decades, it was the physicians' circles - including psychiatrists, geneticists, as well as, biologist - where the pedagogical theory and practice would form in regard to the spectrum of disability. The 19th century, particularly in the highly developed countries of Europe (England, France, Germany) featured the quantitative and qualitative development of special schools and institutions. At the beginning of the $20^{\text {th }}$ century, Germany held the primacy in special education, which is evident from the well developed network of schools, varied forms of aid, upbringing, and education of children with disabilities, as well as, by legislative and methodological solutions. The French, and later, German scholars made attempts to define the object of special pedagogy. In 1861, a work was published by Jan-Daniel Georgens and Heinrich Marianus Deinhardt, which spoke of "curative pedagogy". The issues related to the special education, were given a name, that would place disability between medicine, pedagogy, and psychology. The scholars would use the term "special pedagogue" 4 . Three decades later, Theodor Heller somewhat specified the "curative pedagogy" term. His works, in a form of academic handbooks, were translated into many

${ }^{3}$ J. Bardach, B. Leśnodorski, M. Pietrzak, Historia ustroju i prawa polskiego, Warszawa 1994; J. Makarewicz, Kodeks karny z komentarzem, Lwów 1935; Grotowski, Rozwój zakładów dobroczynnych w Warszawie, Warszawa 1910; F. Skarbek, Pisma pomniejsze, vol. 2. Pisma spoteczne, Warszawa 1827.

4 J.D. Georgens, H.M. Deinhardt, Pedagogika lecznicza (ortopedagogika) ze szczególnym uwzględnieniem idiotyzmu i zakładów dla idiotów, 1861. 
languages including Polish ${ }^{5}$. Heller was dedicated to the issues of psychological disorders and the mental deficiency of children and youth. In his opinion, the tasks of curative pedagogy were not limited to the upbringing of children "that were mentally deficient, but its object would rather encompass all intellectual disorders of the child age, where, by normalising the conditions beneficial for intellectual development, one may expect the regulation of the fractured psychological functions" 6 .

For a number of decades, disability would include four categories of children (in the terminological aspect): blind, deaf-blind, morally neglected, and mentally disabled. Following the terminology of Itard, Esquirol and Seguin, the intellectual disabled persons were classified as: morons (mild intellectual disability), imbeciles (moderate intellectual disability), idiots (profound intellectual disability), cretins (severe intellectual disability). The classification turned out to be overly persistent, as it was used until the 1960s (sic!). One should add, that until the end of the 19th century, the range of interest of pedagogue, included children with severe intellectual disability. During the second half of the $1^{\text {th }}$ century, selective studies were initiated, dedicated to children on the brink of mental disability. It was directly related to the progress within experimental psychology, and the results of the practical activity of newly established physiological laboratories, where school age children would be diagnosed. Studies had become a link of the New Education movement, which, since the end of the $19^{\text {th }}$ century, and in the first decades of the $20^{\text {th }}$ century, had played an essential role within the scope of pedagogical innovation, also in reference to individuals with disabilities. An exemplification of the aforementioned, is the assortment of achievements of the Austrian (William Stern), German (Emil Kraepelin, Wilhelm Wundt, Johann Werze,

5 T. Heller, Studiem zur Blindenpsychologie, 1895 oraz Grundriss der Heilpädagogik, 1904 (Polish translation: Podstawowy zarys pedagogiki leczniczej, Warszawa 1905).

6 O. Speck, Niepetnosprawni w społeczeństwie. Podstawy ortopedagogiki, Gdańsk 2005. 
Bruno Mennel, Arno Fuks, Karl Kern, Anton Joseph Sickinger) and Belgian scholars (Ovide Kraepelin and Jan de Moor). Exceptional achievements in the special education methodology, were the work of the Belgian scholars: Jan de Moor, and Ovide Decroly - the creator of the centres of interest method.

At the beginning of the $20^{\text {th }}$ century the matter of education of the children with disability, at least in well developed countries, was slowly starting to be obvious. In 1903, in Germany, almost 600 special classes functioned in 138 cities, for c. 12 thousand children. Ten years later, already 32771 children and youth would study in 1544 classes. Moreover, at the brink of World War I, a few hundred special schools functioned, for more than 40 thousand students 7 . The concern about children with disabilities, in Germany, was met with large social support. It resulted not only in the largest number of special institutions in Europe, but, to equally advanced legislation. In 1873, in Saxony, compulsory education of children with intellectual disabilities was introduced.

In the legal sense, it is worth noting the British 1886 Idiots Act the 1913 Mental Deficiency Act, and the Prussian 1911 school act For the education of underdeveloped and deaf children ${ }^{8}$.

During the beginnings of the $20^{\text {th }}$ century the issue of disability had become an object of discussions among scholars, organised at the International Education Congresses, and the New Education League. During the 1920s and the 1930s, the sciences indirectly related to special (curative) pedagogy would develop: genetics, psychopathology, children' psychiatry, developmental and educational psychology. At the brink of the 20th century, it was known that, among the children with disabilities, a substantial number of school age children would barely display intellectual disability, or would be mildly disabled, as well as, would be hearing and vision im-

${ }^{7}$ M. Balcerek, Rozwój wychowania i kształcenia dzieci upośledzonych. Zarys historyczny, Warszawa 1981, p. 117.

${ }^{8}$ Ibidem, pp. 57-60; Cf: W. Gasik, Rozwój praktyki i teorii pedagogiki specjalnej w XIX i początkach XX w., [in:] S. Mauersberg (ed.), Dzieje szkolnictwa i pedagogiki specjalnej, Warszawa 1990, p. 92 et. al. 
paired. It was clear, that the organisation of the school network would require far-fetched actions and enormous funds, which, in the face of the social needs caused by the war effort during World War I, and later World War II, was not an easy task ${ }^{9}$.

Maria Grzegorzewska in her script, prepared for the needs of special schools' teachers, while referring to the transformations that would be accomplished in general pedagogy, and special education at the turn of the $19^{\text {th }}$ and the $20^{\text {th }}$ centuries, wrote: "Already in the second half of the 19th century, in general pedagogy, despite the marvellous theories of various pedagogues and philosophers, we see schools - barracks and students - numbers. Gradually, they receive messages about the results of special pedagogy. In time, teachers and theoreticians-pedagogues are turning their attention to it, and this way, data in the form of theoretical inquiries and practical prescriptions, find its way to elementary schools. The educational role of the teacher is starting to grow there, slowly but substantially. The attention of the teacher is starting to move from the object to the subject of teaching - he is getting closer to the child, and he starts to see it and its development within the environment, care about the child's future fate. Therefore, there is an increased interest with the work method and its organisation, cooperation with home, and finally, with normalising certain psycho-physical irregularities of the child / speech disorders, the conditions of the eye, ear, an illstate of the health of the child, of its physical development, etc./ as well as, removing or compensating certain negative conditions /physical and psychological/ of education in the household environment that impede the development of the child /e.g. additional nutrition, health care, better lighting, the ban on physical punish-

${ }_{9}$ See: T. Bilikiewicz, J. Gallus, Psychiatria polska na tle dziejowym, Warszawa 1962; O. Lipkowski, Wychowanie dzieci społecznie niedostosowanych, Warszawa 1966 /regarding the Western European accomplishments in regard to the development of care and special education in the $19^{\text {th }}$ century/; M. Kalinowski, M. Pełka, Zarys dziejów resocjalizacji nieletnich, Warszawa 2003; J. Wyczesany, Pedagogika upośledzonych umystowo, Kraków 2007; Z. Sękowska, Wprowadzenie do pedagogiki specjalnej, Warszawa 1998; S. Mauersberg (ed.), Dzieje szkolnictwa i pedagogiki specjalnej, Warszawa 1990; H. Borzyszkowska, Oligofrenopedagogika, Kraków 1998. 
ment, ill-treatment, explaining the needs of the particular child, etc./. This is already entering the area of broadly perceived preventive action. Removing shortcomings, and the negative influences of the surroundings, enhancing the psycho-physical endurance of the student, in other words, it is the removal, the normalisation, the compensation of the negative educational conditions that are within the child and within the conditions of his household environment, that may cause certain irregularities, shortcomings and developmental impediments"10.

\section{The origins and the development of special education in Poland}

Special education in Poland began institutionally, as was already mentioned, when the Government Committee for Religion and Public Enlightenment assigned rev. Jakub Falkowski, with the mission of establishing the Deaf-Mute Institute. First, the institute was to be located in Szczuczyn, but after the enterprise's fiasco in 1816, schooling of deaf-mute students in the Kingdom, actually began in October 1817. The first decade in the functioning of the institute, featured an assortment of difficulties related to the lack of both the teachers, and of the space in which the education would take place. It is worth adding, that rev. Anzelm Zygmunt, the creator of the first fingerspelling alphabet, the graduate of the Deaf-Mute institute in Vienna, created the first institution in the Romanov empire, in Pavlovsk near Petersburg, in 1806. During the first years, the Warsaw Deaf-Mute Institute consisted of 30-40 students, including girls. From the half of the twenties, c. 60 students would be educated there, including 15 girls $^{11}$. In the didactic work of the institute,

${ }_{10}$ M. Grzegorzewska, Skrypt wykładów w Państwowym Instytucie Pedagogiki Specjalnej, Warszawa 1960, p. 6.

11 A. Winiarz, Szkolnictwo Księstwa Warszawskiego i Królestwa Polskiego (1807-1831), Lublin 2002, pp. 145-151; O. Lipkowski, Początki szkolnictwa specjalnego, [in:] Ł. Kudybacha (ed.), Historia wychowania, vol. 2, PWN, 1968, pp. 206-212. 
a crucial task was the professional preparation, with even 23 types of specialisation in c. 1830. The matter of education, including the autonomisation and socialisation of the students, was the organisational basis of the institution, and was successfully continued in the following decades under the supervision of Wawrzyniec Wysocki, Józefat Szczygielski, and Jan Papłoński. In 1842, in the Deaf-Mute Institute, the first in Poland branch of the education of blind children, was launched ${ }^{12}$. The Deaf-Mute Institute, skilfully managed by Falkowski, and then his successors, resisted the russification attempts of the tsar's administration in the kingdom, long and efficiently. The situation changed only at the end of the 1880, when the control over the institute was taken by Russian supervisors: Michał Kornilewicz Ziemiec, Afanasij Dmitrewicz Błagowieszczański, Stiepan Grigorewicz Jakowienko, Erwin Magnuszewicz Jurgens, and Wsiewołod Wasiliewicz Własow ${ }^{13}$. The war events from the World War I period, particularly the evacuation of the Russians from the Kingdom of Poland in 1915, turned out to be sinister for the Institute, whose equipment and capital, along with the staff, were evacuated to Russia.

In the Prussian partition, the first Institution for the Deaf-Mute, began its operations in a teachers' seminar in 1832 in Poznan. The institution was formed after the Berlin institute, and what is important, it conducted pioneering attempts to educate teachers of deaf children. In 1871, the Institution for the Deaf was founded in Bydgoszcz. In 1911, in Germany, legislative prescription for the education of deaf children was introduced, which was in motion also in the Polish territories of the Prussian partition ${ }^{14}$.

In the Polish territories of the Austrian partition, the first institution for deaf-blind children was founded in Lviv, in 1830. The Institution was largely inspired by the Warsaw institute. In 1870, the

12 L. Karpińska, Zarys dziejów warszawskiego Instytutu Głuchoniemych i Ociemniałych w latach 1817-1917, [in:] O. Lipkowski (ed.), O wychowaniu dzieci głuchych. W150-lecie Instytutu Głuchoniemych i Ociemniatych w Warszawie, Warszawa 1967.

13 E. Nurowski, op. cit.

14 Tamże, pp. 110-111. 
second institution for the deaf children, known as the Jewish School for the Deaf-Mute, was launched in Lvivis.

One should highlight, that regardless of the border cordons of the partition countries, the institutions for the education of the deaf in Poland, wrote down a beautiful record in its activities. The teachers were authors of numerous valuable scientific publications and methodological aid, under Jan Papłoński in Warsaw, and in Lviv: Tomasz Chocholouzek, Antoni Mejbaum, Bogumiła Wilkosz, Mieczysław Krajewski, rev. Wilhelm Wagner et al. ${ }^{16}$.

The organisation of special education for blind children, practically began in the half of the 19th century. In working with the blind children, efforts were made to optimise their life self-sufficiency. The function was accomplished by vocational training, organisation of orchestras, and musical associations. In 1864, from Jan Papłonski's initiative, the Blind Musicians Society was launched, including c. 50 members ${ }^{17}$. The society successfully conducted and expanded its activity, also involving the families of the blind persons, for subsequent decades. Starting with 1842, in the Warsaw branch of the blind, from more than a dozen to a few dozen blind students would be educated. During the school years 1886/87 and 1907/08, respectively 43 and 44 students were accepted, the highest rates throughout the years. In 1851, the only institution for the Blind had begun its activity in Lviv. Until the 1890s. 128 boys and 44 girls were educated in the institution. The institution created the possibility to educate a much higher number of students, however, there were few attendants. The graduates could hope for financial aid after finishing their education, particularly in a situation, when it was related to starting their own professional activity ${ }^{18}$. The education curriculum was the work of the teachers (lesson scenarios, hand-

15 M. Pękowska, Lwowskie zakłady dla głuchych i niewidomych dzieci w latach 18301914, Kielce 2003.

16 Tamże, p. 119.

17 E. Grodecka, Historia niewidomych polskich w zarysie, Warszawa 1996.

18 Ibidem, p. 16. 
books and educational aid), who referred to the curricula of the 6-grade popular schools. During the lessons, schooling was considered from subject matter such as: religion, convex print reading (using the Wilhelm Klein method), writing, Polish and German language, arithmetics, history of Poland and the Austro-Hungarian empire, natural sciences, singing, violin, pipe organs, and piano playing. Moreover, an assortment of craftsmanship specialities was introduced, both for the boys and the girls (shoemaking, basketry, needlework, crochet, weaving, et al.). Meticulous physical education was given high status ${ }^{19}$.

During the 1830, under the Prussian partition, the record of blind persons was conducted, which showed, that the "Poznan province" was inhabited by almost 700 blind persons (including 55 children of school age), on 1 million inhabitants. In 1853, an institution for the blind was organised in Wolsztyn. In 1872 it was transferred to Bydgoszcz (Provincial Institution for the Blind). The establishment included children and youth from almost the entire Prussian partition. Schooling was conducted using Braille. The students would be educated in the following professions: organist, instrument tuner, brush-maker, printer, massagery ${ }^{20}$. In 1889, in Bydgoszcz, the Society for the Care of the Blind had begun its operation, possessing own library, and Braille printing works.

In Polish territories, the education of children with intellectual disabilities, was taken care of at the end of the 19th century, as in 1897, in Poznan a special school at Wielkie Grabary 25 street began its activity. Until 1909, 100 students, including 43 girls, were educated in five units of the school. In Silesia, inspired by the solutions adopted in Germany, numerous special classes functioned in: Bytom, Piekary Śląskie, Lubliniec, Szopienice, Świętochłowice, and

${ }^{19}$ M. Pękowska, op. cit., pp. 108-110; J. Kuczyńska-Kwapisz, Dzieje ksztatcenia niewidomych na ziemiach polskich i perspektywy rozwoju wspótczesnej tyflopedagogiki, „Roczniki Pedagogiki Specjalnej”, vol. 8, 1997, pp. 43-57; E. Bendych, Powstanie i rozwój tyflopedagogiki w Polsce, [in:] U. Eckert, K. Poznański (eds.), Pedagogika specjalna w Polsce, Wyd. WSPS, Warszawa 1992, pp. 127-133.

${ }^{20}$ E. Grodecka, op. cit., pp. 27-28. 
Leśnica Opolska. During the beginning of the 20th century, special schools were organised in Chorzów (1904) and in Katowice (1906) ${ }^{21}$.

Until World War I, in the Austrian partition, 3 special schools for children with severe intellectual disability, were founded: in Równe (1904), Lviv (1911), and in Cracow (1912). From the initiative of prof. Jan Piltz, the first institution in the Polish territories, for children with deviations from norm, was established in 1912, in Cracow. The Cracow Neurological-Psychiatric Society would conduct the diagnostic studies. The first special class for children with mild intellectual disability (morons) was organised in 1918. ${ }^{22}$ The scope of the care provided for children with intellectual disabilities in Galicia, was one of the least developed in the entire Habsburg monarchy. The State Psychiatric Institution in Kulparków, established in 1875, was dedicated to the treatment and care of persons with psychological disorders. In 1889, the Nursing Home for Persons with Psychological and Nervous Disorders was established in Lviv, and it was the only institution of such kind in Polonia Minor, until the outbreak of World War I ${ }^{23}$.

Starting with 1814, in the Kingdom of Poland, the primary role in the care for the needy was played by the Warsaw Charity Society (Warszawskie Towarzystwo Dobroczynności) that provided varied forms of aid, also for people with disabilities, threatened by social exclusion $^{24}$. During the beginnings of the 1880s, Warsaw Children's Friends Society, inspired by the French societies of such kind, had begun its functioning. The founders of the Society referred to the tsar's 1881 Manifesto, where notions were made, i.a. regarding the action for care for the family in regard to the fight against demorali-

21 W. Gasik, op. cit.; A. Giryński, Rozwój szkolnictwa specjalnego dla osób upośledzonych umysłowo w Polsce, „Roczniki Pedagogiki Specjalnej”, vol. 8, 1997, pp. 9-15.

22 Ibidem, pp. 101-102.

${ }^{23}$ M. Balcerek, Rozwój wychowania i ksztatcenia..., p. 61.

${ }^{24}$ H. Markiewicz, Działalność opiekuńczo-wychowawcza warszawskiego Towarzystwa Dobroczynności, 1814-1914, Warszawa 2002, Pelczar, Zarys dziejów miłosierdzia w Kościele katolickim, Warszawa 1916, p. 170. 
sation, poverty, various pathologies, austerity, etc. ${ }^{25}$ The first units for children with disabilities were created by Michalina Stefanowska - a scientist, physician, and a social activist. The results of her years of work, were the first units in the Kingdom of Poland, for "mildly able" children, that went operational in 1917. As a result of the initiative of the Children Studies Society (Towarzystwo Badan nad Dziećmi), Stefanowska, would also perform selective studies, and the qualification of children for special schools. Moreover, she assumed auspices over the organisation of six-week courses regarding the education of teachers from Warsaw special schools - within the scope of intellectual disabilities ${ }^{26}$. One may surely highlight, that, with her activity, Stefanowska carved a path for Maria Grzegorzewska, who, since 1919, consequently proposed the institutional education of the teachers of special schools, which finally came to pass in the half of 1922, along with the institution of the State Institute for Special Pedagogy (Państwowy Instytut Pedagogiki Specjalnej - later abbreviated as PIPS). Leading pedagogues participated in her courses organised for the special schools' teachers, particularly: Czesław Babicki, Janusz Korczak, Józefa Joteyko, and Maria Grzegorzewska. Additionally, one should remind, that Stefanowska, along with the school inspectorate of Warsaw, performed selective studies of children suspected of mental disabilities. She was supported by dr Władysław Sterling, a well known hygienist and a Warsaw physician ${ }^{27}$.

${ }^{25}$ Niedole dziecięce. A joint monograph published by the Enthusiasts of the Child Age, (Miłośnicy Dziecięcego Wieku), Warszawa 1882, pp. 1-17.

26 E. Kubeczko, Michalina Stefanowska, „Szkoła Specjalna”, no 2, 1968, pp. 130-131; Radziszewska, Jeszcze jedna rocznica w historii szkolnictwa specjalnego dla dzieci upośledzonych umysłowo w Warszawie (1917-1922), „Szkołą Specjalna”, no 2, 1968, p. 137 /in 1918, by M. Stefanowska's initiative, the second (in 1918), and third (1919) editions of the course for special schools' teachers were launched. In the school year $1919 / 1920$ the education of teachers was conducted within the framework of the "Yearly seminar course for the teachers of mildly able children, and with personality flaws"/.

${ }^{27}$ Radziszewska, op. cit., pp. 146-147. 


\section{The Second Polish Republic}

Initially, the development of special education in the Second Polish Republic was a domain of the people of good will (physicians, pedagogues, social activists) and local city governments. Due to the involvement of such people, the subject matter of special education was debated, what is important, at the forum of the first national educational convention in April 1919, in Warsaw. There, the postulate was submitted to cover the children with disability with legislative compulsory education ${ }^{28}$.

In 1920, the Faculty of Special Schools of the Ministry of Religion and Public Enlightenment, supervised by Jan Hellman, had gone operational. The faculty existed, but for a couple of years (until the 1924), and later was incorporated into the structures of universal education. The decision was, to a degree, an exemplification of the educational policy realised in regard to children with disabilities, which had secondary meaning. The thesis was confirmed by Maria Grzegorzewska's statements, who i.a. wrote at the "Special School" („Szkota Specjalna") forum ${ }^{29}$. To a degree, it seems understandable, that in the education department, the subject matter of special education, was withdrawn to secondary importance, in the face of the enormity of the challenges standing before the young state. In 1919, children with disabilities had been formally subjected to universal, compulsory education, however, the execution of the decision was practically impossible, considering the low development of schools and special institutions. It is estimated, that at the brink of the 1918,

28 O szkołe polska. Pierwszy Ogólnopolski Wielki Zjazd Nauczycielski 14, 15, 16 i 17 kwietnia w Warszawie, Lwów - Warszawa 1919; S. Mauersberg, Opieka nad dzieckiem i szkolnictwo specjalne, [in:] Historia wychowania wiek XX, (ed.) J. Miąso, vol. 1, PWN, Warszawa 1980, pp. 105-111; S. Michalski, Praca naukowo-badawcza nauczycieli w Drugiej Rzeczypospolitej, Wyd. UAM, Poznań 1994, pp. 84-107.

${ }^{29}$ M. Grzegorzewska, Szkolnictwo specjalne, [in:] S. Łempicki, W. Gottlieb, B. Suchodolski, J. Włodarski (eds.), Encyklopedia wychowania, vol. 3, ed. 1, Warszawa 1937-1939; M. Grzegorzewska, Państwowy Instytut Pedagogiki Specjalnej w Warszawie, „Szkoła Specjalna”, no 1, 1924. 
c. 30 special institutions were functional. Until the outbreak of World War II, c. 120 special elementary schools had been founded, for c. 12 thousand children: with intellectual disabilities, blind, deafmute, and morally neglected. The Polish special education system of the interwar period, failed to organise preschools, vocational schools and middle schools. Actions were initiated for the education of children with chronic conditions, and disabilities, within the framework of nursing homes and preventoria, however, this form of education was mostly developed in the postwar period ${ }^{30}$.

The special education base in the interwar period was not balanced, with the prevalent number of schools in the central and western Poland ${ }^{31}$. Most schools were located in buildings that required renovation, not to mention that they were not well equipped. The situation, further strengthened by numerous social barriers, and stereotypes related to the lack of knowledge on the rehabilitation of children with disabilities, resulting in the views of the majority of the society, resulted in the fact, that c. $85-90 \%$ of children did not attend compulsory education. Preventing the aforementioned required meticulous, multidimensional, and long-lasting activities. The circles of the special schools' teachers promoted Korczak's ideal of the subjectification of the child, along with the statement that "There is no cripple, it is a Man", postulated on conferences, congresses, gatherings, and within pedagogical work ${ }^{32}$.

${ }^{30}$ M. Zaorska, Rehabilitacja i edukacja osób z niepetnosprawnością sprzężoną w kontekście historycznym i stan aktualny, [in:] J. Błeszyński, D. Baczała, J. Binnebesel (eds.), Osoba z niepetnosprawnościa - opieka - terapia - wsparcie, Łódź 2008, pp. 79-104.

${ }^{31} \mathrm{H}$. Ryll, Stan szkolnictwa specjalnego w ostatnim piętnastoleciu, „Szkoła Specjalna", no 1-2, 1938/39, p. 147 et al. /c. 50\% schools functioned in the central Voivodeships, c. $30 \%$ in the western Voivodeships, $8 \%$ in the eastern Voivodeships, and c. $6 \%$ in the southern Voivodeships. Generally speaking (with retaining the original writing) the mentally disabled children accomplished the compulsory education in $12 \%$, deaf children in $15 \%$, blind children in $20 \%$, and morally neglected children in $10 \% /$.

32 The rights of children with disabilities were guaranteed in the 1921 March Constitution /Law Gazette, no 44, pos. 267/ and in the March 1932 School Act of Janusz Jędrzejewicz /Law Gazette of the Polish Republic, 1932, no 38, pos. 389/. 
During the interwar period the Special Education Section was established (1924), founded by Maria Grzegorzewska at the Universal Schools Teachers' Association (Związek Nauczycielstwa Polskiego Szkół Powszechnych). The same year, the "Special School" journal, had become the instrument of the Section - edited as a scientific quarterly. Through subsequent years, "Special School" was the only professional journal for special pedagogues in Poland, and, importantly, due to its high substantive matter, if accomplished its mission with success.

The teachers of special schools were educated in the only institution of the time, which was the State Institute for Special Pedagogy (Państwowy Instytut Pedagogiki Specjalnej - 1922). Many of them participated in the nationwide congresses of teachers of special schools and institutions, organised under the auspices of the Institute, in 1925 and 1934. The advanced preparation efforts for the third congress, that was meant to take place in September 1939 in Vilnius, were stopped by the tragic events of World War II33.

\section{World War II}

War and occupation of Polish territories in the 1939-1945 period - in regard to children with disabilities - was no less dramatic, than to the entire nation threatened with biological annihilation by the Nazi occupants. In the General Government area, the fate of special schools depended on financial means. The German administration had not issued a formal decision about shutting down this type of schools. Few special schools survived the war: in Kraków, Lublin, Siedlce, Piotrków Trybunalski, Laski, and in Warsaw until the Warsaw Uprising. According to calculations by Janina Kaźmierska, until

33 See: The reports from the I and II congress of special school teachers, published in (in extenso) the 1925 and 1934/35 volumes of "Special School"; Cf. W. Jamrożek, Kongresy i zjazdy pedagogiczne w rozwoju polskiej myśli i praktyki edukacyjnej (do 1939 roku), Poznań 2015; M. Balcerek, Rozwój szkolnictwa specjalnego i opieki nad dzieckiem w Polsce okresu międzywojennego, "Rozprawy z Dziejów Oświaty”, vol. 12, 1969, pp. 143-225. 
1944, 13 special schools for 1748 students survived. It is worth mentioning that a few dozen special school teachers (from Warsaw alone) took part in underground education ${ }^{34}$.

The policy of the German occupants in Polish territories, aimed at the extermination of weak, sick, crippled, mentally ill, and disabled individuals. The extermination included the patients of the psychiatric hospitals in: Choroszcza, in the St. John of God Hospital in Warsaw, in Kochanówka near Łódź, and in Kocborowo. In the Lubliniec psychiatric hospital, the children with mental disabilities were killed by administering increased doses of Luminal ${ }^{35}$.

The postwar fate of special education in Poland were, to a significant degree, marked not with the activities of the local or social factors, but the supreme authorities of state administration. The losses in education of all types were severe, as they amounted to $60 \%$ of the pre-war state. Initially, considering the change of borders, primarily, attempts were made to stop the wave of illiteracy, and to ensure that the children attend the compulsory education. Almost until the end of the 1940s, solutions were employed, that were developed in the pre-war period (acts, resolutions, school manuals, forms, etc.). Staff shortages - in the face of the death of c. 10 thousand pedagogues - were to be filled with teachers who were educated in a rush, often allowed to work after only a few preparation courses. Additionally, regarding special education, many merited pedagogues and PIPS graduates died. Those included, I.a. Michał Wawrzynowski (the special education school inspector, the creator of the curriculum of educating persons with intellectual disabilities), Halina Jankowska (a lecturer of psychopathology), Zygmunt Kurletto (dedicated to physical education), Jakub Segal (a lecturer of psychology), Władysław Sterling (a lecturer of psychopathology). It is assumed, that in general, it was 64 individuals ${ }^{36}$.

34 W. Gasik, Szkolnictwo specjalne w latach wojny i okupacji (1939-1945), [in:] S. Mauersberg (ed.), Dzieje szkolnictwa i pedagogiki specjalnej, Warszawa 1990, pp. 240-247.

35 Madajczyk, Polityka okupanta wobec narodu polskiego, Warszawa 1961; A. Götz, Obciążeni. Eutanazja w nazistowskich Niemczech, Wyd. Czarne, Wołowiec 2015.

${ }_{36}$ M. Grzegorzewska, Losy wojenne i odbudowa Państwowego Instytutu Pedagogiki Specjalnej, „Szkoła Specjalna”, no 1, 1946/47, pp. 6-12. 


\section{The postwar period}

Since the end of the 1940s, the educational system in Poland, was subject to complete reorganisation. From now on, the directions of school reforms would be determined by the party circles realising the ideas of educational standing in opposition against the Western European achievements. One should notice, that the quantitative development of particular types of schools, including special education, came at the expense of the quality of education. The educational policy, particularly the one from the first half of the 1950s; was of doctrinal nature. In order to limit the role of the PIPS - treated by the overzealous ideologues, as a peculiar organisational relic based on Western European models - it was reduced to the role of a study dedicated to the education of teachers (1950 statute). The "Special School" quarterly was shut down. The next step was the administrative decision regarding the introduction of subject teaching in special schools. During the first half of the 1950s, the first school handbooks were printed and introduced. The handbooks were prepared even by people, that, previously, had in no way been related to the methodology of special education ${ }^{37}$.

During the first half of the 1950s, under the influence of Poznan (June) events, and the Polish October, the political scene was shuffled, resulting in a revision of educational policy. The special school teachers gladly accepted the retraction of the resolution regarding the subject education, the return of the "Special School", the restoration of the ZNP Special Education Section, the restoration of the PIPS" scientific-scholarly status. The 23 March "On compulsory education” („O obowiazku szkolnym”), was an important decision, as its

37 J. Kulbaka, Szkolnictwo specjalne w polityce w polityce społeczno-oświatowej państwa w latach 1944-1948, "Przegląd Historyczno-Oświatowy”, nr 3-4, 2005; Idem, Szkolnictwo specjalne w pracach ministerstwa oświaty w okresie przygotowań $i$ realizacji planu sześcioletniego (1950-1955), "Przegląd Historyczno-Oświatowy”, nr 1-2, 2007; Idem, Szkolnictwo specjalne $w$ Polsce $w$ pracach Ministerstwa Oświaty w latach 1956-1961, „Przegląd Historyczno-Oświatowy”, nr 1-2, 2009. 
introduction created the actual chances of expanding schools, and special institutions, and, therefore, chances for increasing the universal nature of teaching in this aspect of education ${ }^{38}$. The fate of the children with disabilities, have become the object of the sessions of the Sejm Committe of Education (Sejmowa Komisja Oświaty i Nauki) in 1957 and $1958^{39}$. During the half of the 1950s, only 30\% of special care children, received education, and there would be one special school in a thousand secondary schools ${ }^{40}$. In five years (1956-1961) c. 100 new special schools were launched, including the first special institutions for children with disabilities in Police and Płakowice. The estimates show, that at the turn of the 1950s and the 1960s, c. 50 thousand children and youth with disabilities were attending 500 schools $^{41}$. It was a good thing, that the expansion of special schools was included in the 1958 "monument schools" ("szkoły pomniki") national plan, for the millenary jubilee of Poland, which was crucial for the educational building investments in the entire decade of the $1960 \mathrm{~s}^{42}$.

In 1958, the first Department of Special Pedagogy was established, at the University of Warsaw. The event was momentous, as for the first time in Poland, the education of the special school teachers, received the academic status. In the decades of the 1960s and the 1970s, the issues of disability, was included in the curricula of other universities, and higher pedagogical schools. Special pedagogy had received the status equal to other subdisciplines of pedagogy, at universities in: Poznań, Toruń, Gdańsk, Katowice, Kraków, Łódź, and Lublin, Wrocłas, as well as, higher pedagogical schools

3823 March 1956 decree (Law gazette, 1956, no 9, pos. 52).

39 The Archive of New Records, The PPR Parliament II Term, 1957-1961.

${ }^{40} \mathrm{M}$. Rachoński, Aktualne problemy kształcenia zawodowego młodzieży upośledzonej umystowo, [in:] Wychowanie dzieci upośledzonych umystowo. Sekcja Szkolnictwa Specjalnego, Warszawa 1960, pp. 62-81.

${ }^{41}$ GUS, Polska w liczbach, 1962, p. 67; J. Kulbaka, Szkolnictwo specjalne w Polsce..., pp. 82-100.

${ }^{42} \mathrm{~K}$. Wałaszewski, Tysiąc szkót na Tysiąclecie: Szkoty Tysiaclecia - architektura, propaganda, polityka, Łódź 2018. 
in: Bydgoszcz, Częstochowa, Kraków, Rzeszów, and in Warsaw, as a result of establishing the Maria Grzegorzewska University ${ }^{43}$.

From 1961, to the end of the Polish People's Republic, or, more precisely, to 1991, the directions of special education were determined by the 15 July 1961 School Act titled "On the development of the upbringing and education system" ("O rozwoju systemu oświaty $i$ wychowania" $)^{44}$. Article 20 of the act, states that "The education and the upbringing of children and juveniles, suffering from chronic diseases, mentally retarded, and with physical and intellectual disabilities, are conducted in special preschools, schools, and units in elementary schools, or schooling and educational institutions. Special schools and institutions provide the youth with educational, care, schooling to an available degree, and preparation for an appropriate profession" 45 .

The works of the Ministry of Education and of the Council of Ministers for children with disabilities, were supported by the Sejm. The object of the works of the Sejm Committe of Education (III term), was particularly, the children with intellectual disabilities, children and youth with social maladjustment, as well as, children with chronic conditions, and physical disabilities. The works were continued in subsequent years (IV term Sejm) ${ }^{46}$.

In the 1960s, under the 1961 school act - the educational administration introduced statutes of special elementary schools, educational institutions, and schooling-educational centres. New core curricula, educational aid, and educational curricula, have appeared. The actions were accompanied by the quantitative expansion of special schools and institutions, that had become a visible element of the school system ${ }^{47}$.

${ }^{43}$ Law gazette, 1976, no 15, pos. 93 /The 2 April 1976 edict by the Council of Ministers regarding the creation of Maria Grzegorzewska University/.

44 Ustawa o rozwoju systemu oświaty i wychowania w Polsce Ludowej, Warszawa 1961.

45 Ibidem.

46 Sejm Library: The Index for Stenographic Reports from the PRL Sejm for III term (1961-1965) and for IV term (1965-1969).

47 Regarding the activities for special education in the 1960s, we find valuable information in the Archive of the Ministry of National Education in Warsaw. See: 
During the 25 years after the end of World War II, the system of special education in the People's Poland, was based on special schools (segregation model) and included the education of children (according to the terminology of the time): mentally retarded, blind, visually impaired, deaf-mute, hearing impaired, with chronic conditions, as well as, crippled, and children with multiple disabilities. Additionally, apart from the special public/elementary schools, known from the Second Polish Republic, in post-war Poland, special preschools and vocational schools functioned. It is worth mentioning that the 1961 school act, allowed for organising special classes in mainstream schools, which helped accomplish the universal character of education ${ }^{48}$. In the 1960s the special education expanded by 71 new, established from the ground-up, school buildings, not to mention objects adjusted for educational purposes, and in the entire 1961-1971 decade, c. 1 thousand special classes were established 49 .

The 1970s decade consisted of the further development of special schools and institutions in Poland, with particular focus on vocational preparation, and the employment of special schools' graduates in cooperatives for the disabled, and employment establishments. The most information about the education department's plans regarding special schooling, is provided by the "Directives on the development of special education, and the aid for children with deviations and developmental disorders" ("Wytyczne w sprawie rozwoju kształcenia specjalnego $i$ pomocy dzieciom $z$ odchyleniami $i$ zaburzeniem

The Ministry of Education, File Catalogue A., sign.: 538/4 (regarding the school inspections in each school board, reports, and budget issus/; 476 (2) /information regarding the network and organisation of special education/; 133/2 / budget plans for 1969 and 1970/.

${ }^{48}$ W. Doroszewski, Sprawy terminologiczne, "Szkoła Specjalna”, no 1, 1969, pp. 1-4. Regarding the organisation of special classes, a directive was issued by the Ministry of Education (See: Official Gazette of the Ministry of Education, 1961, no 12 , pos. 159).

${ }^{49}$ J. Nowakowski, Drogi przebudowy szkolnictwa specjalnego, „Szkoła Specjalna”, no 3, 1965. 
rozwojowym"), issued by the Ministry of Education in $1973^{50}$. A premise was assumed, that each county should have at least one special school for children with intellectual disabilities. Additionally, plans were made, that the blind and death children would be registered by name. The education department planned to establish closer cooperation with social organisations (i.a. ZHP, TPD, PZG, PZN), with cooperatives for the disabled, in order to optimise and increase the level of education and employment of persons with disabilities, as well as, to provide them with appropriate health care in schools and in educational institutions. Much emphasis was placed on the activity of educational-vocational counselling.

From the very beginnings, the accomplishment of this ambitious plan of a qualitative enhancement of the pedagogical work, and of special schools, had met with numerous obstacles, particularly since the second half of the 1970, marked with the economic crisis of the country. The realisation of the Directives was eventually put to a halt, as the entire school reform, announced in the resolution, approved by the Sejm unanimously on 13 November 1973, in result of the economic crisis, and the political events (the martial law). The ambitious plans of the Ministry of Education, assuming, that at the turn of the 1970 s and the 1980 s, $70-80 \%$ of children would receive special education, were not accomplished ${ }^{51}$.

Similar to the 1950s and the 1960s, the situation of special education, had once again become an object of Sejm debates, and, to an even larger degree, an object of discussion among opinion-forming

50 Założenia programowo-organizacyjne w dziesięcioletnich szkołach specjalnych, Warszawa 1977.

51 Sejm Library, The Committee of Education Press Newsletter, no 40, 1970, 94, 1972, 97, 1972 (PRL Sejm, VI term); sign. 323/VII (PRL Sejm, VII term); See also: The Archive of the Ministry of National Education in Warsaw Archive, Catalogue A., sign.: 177 /the synopsis for special education for 1972/, 180 /the works of the Department for the Organisation of Studies and Synopses of the Ministry of Education/, 258 /the works of the Office for the Reform of the National Education System/, 270 /the activities Education Council/, 280 /the organisation plans for special education for 1972-1973/, 376 (the report on the organisation and the functioning of special education for 1965-1975/. 
factors (radio, press, television) In 1982, after a few days of Sejm proceedings - preceded by the sessions of Sejm committees in cooperation with education, health and social care, employment and justice departments, a "16 September 1982 Resolution of the Sejm of the Polish People's Republic for the crippled and the persons with disabilities" („Uchwata Sejmu Polskiej Rzeczypospolitej Ludowej z 16 września 1982 r. w sprawie inwalidów i osób niepetnosprawnych") was issued ${ }^{52}$. The resolution, apart from the 1961 school act, determined the direction of activities for persons with disabilities, until the fall of the Polish People's Republic. The 1982 resolution, despite being issued in particularly difficult times, had essential significance in the aspect of revealing the spectrum of malpractices, needs, and remedial actions, in the system of diagnosis, counselling, education, material aid, and employment of persons with disabilities, as well as, of the everyday and lifespan conditions of life of these persons ${ }^{53}$. The works of the Sejm committees, and subcommittees had proven, that the material situation of disabled individuals and adults was particularly disturbing ${ }^{54}$.

Despite many shortcomings and forbearances resulting from the difficult material situation of the country, almost during the entire postwar period, the system of special education in Poland, at the end of the 1980 s, included c. $75 \%$ children and youth with disabili-

52 See: "Szkoła Specjalna”, no 1, 1983 (the complete text of the resolution); Cf. Sejm Library, The Index for Stenographic Reports from the PRL Sejm for VIII term (1980-1985).

53 Biblioteka Sejmowa, Biuletyn Prasowy Komisji Oświaty i Nauki. Skorowidz do sprawozdań stenograficznych z posiedzeń Sejmu PRL: VIII Kadencja (1980-1985), IX Kadencja (1985-1989).

54 Index..., PRL Sejm (VIII term), pp. 74-76 /it is clearly shown by the statement of representative Jan Szczepański: "In the past period, one could, and can probably still see not only the increase of the indifference, but even hostility of the social cruelty towards persons with disabilities. The facts are known, the press wrote about it many times, and many moral calls were made towards the society. The situation indicates an urgent need of a particular activity of the state and social institutions (...). The issues of the crippled and persons with disabilities are numerous"/. 
ties, that would attend special institutions. One must state, that it was caused by numerous factors (state educational policy, social material level, economic crisis, social barriers, et al.). One should also note, that particularly, since the 1960s and the 1970s, counselling, diagnostics, selection, and qualification of children for special institutions, had been improved. One should remind that the examination of children for special schools during the Second Polish Republic, was performed in the State Institute for Special Pedagogy, within the framework of counselling (orthophonic) and workshops (psycho-pedagogical, preventive). Similar, in the first years following World War II, until the school administration had been obligated to a pre-selection of children that were presumed as intellectually disabled, conducted in primary (elementary) schools. At the turn of the 1950s and the 1960s, the field school staff (inspectors), apart from their task of recording children at school age, was additionally obligated to cooperate with pedagogical councils, parents' committees, and doctors, in order to prepare an index of children with disabilities, who yet remained outside of school. In the 1950s, the matters of selection and qualification of children for special education institutions, were subject to correction. The 1951/52 school year instruction contained guidelines that show, that the pre-selection, mostly related to identifying children with intellectual disabilities, was conducted in schools, by pedagogical councils, later in by the departments of education within the national council presidiums (county and city). The final decision was made at the level of Voivodeships' departments of education within national councils, after consulting the special school inspectors, and social organisations ${ }^{55}$. At the brink of the 1960s, regulations were introduced, regarding the selection of deaf, and hearing impaired children. On their basis, selection committees were established in: Kraków, Ponzań, Warsaw,

55 The instruction regarding the organisation of the 1951/1952 school year for special education (Official Gazette of the Ministry of Education, no 7, item 78, 1951); Cf: the 1952/1953 school year instruction (Official Gazette of the Ministry of Education, no 6, item 48, 1952). 
Wejherów, and Wrocław ${ }^{56}$. During the first half of the 1970s, the Educational-Vocational Counselling Statute (Statut Poradni Wychowawczo-Zawodowej), was prepared, as an addendum to the resolution of the Minister of Education, from this very year. Educationalvocational counselling units functioned until 1993, when they were transformed into psychological-pedagogical units ${ }^{57}$.

In the 1970s and the 1980s, within the scientific and educational circles, there was an increasing notion regarding the need of remodelling the existing forms of special education in the spirit of integration. It is proven by, i.a the texts published in "Special School", during the postwar period. Additionally, one must note, that Poland was a signatory of numerous international agreements (UN), regarding the protection of the rights of persons with disabilities ${ }^{58}$.

The scale of disabilities, which had become an important element of social life, was proven, i.a. by the 1982 census. The gathered data showed, that c. 3,5 million persons with disabilities (children, youth, adults) lived in Poland. However, the statistics had an upward trend, as shown by the subsequent 2002, and 2012 censuses.

\section{Summary}

Special education in Poland was initiated by people of good will and social organisations during the partition period, for four categories of children: deaf-mute, blind, with intellectual disabilities, and morally neglected. The development of the methodology of special education was a resultant of the individual accomplishments of the teachers from particular schools and special institutions, as

56 Official Gazette of the Ministry of Education, no 4, item 49, 1960 (a directive regarding the operation of the county selection committees for children with hearing and speech impairment).

57 Official Gazette of the Ministry of National Education, no 67, pos. 322, 1993.

58 A. Hulek, Pedagogika rewalidacyjna, Warszawa 1980; Tenże, Stan obecny i kierunki przebudowy ksztatcenia specjalnego w Polsce, PWN, 1989; E. Nurowski, pedagogika specjalna w szkolnictwie powszechnym, WSiP, Warszawa 1991. 
well as, of the reception of the European thought within the frameworks of the "curative pedagogy". At the brink of regaining independence by Poland, numerous institutions were known for long lasting history and didactic achievements. In the quantitative aspect, special education was still in an organisational phase, and could meet the existing needs to but a small degree.

In the interwar period, the education of the teaching staff, counselling, and studies in special pedagogy were organised (PIPS). The union activity of special schools teachers was initiated (The Special Education Section), along with publishing effort within each subdiscipline of special pedagogy, i.a. in the Library of the Special Education Section, and "Special School".

During the end of the 1930s, the special education base was modest, as it provided education to only $10-15 \%$ of children at school age. Despite the attempts taken during the interwar period, the establishment of special preschools and vocational schools failed. It seems, that the greatest surplus of special education consisted of people such as Janusz Korczak and Maria Grzegorzewska, that, out of the kindness of their hearts, acted for the sake of "abnormal" children, according to the existing terminology.

The evaluation of the accomplishments of special education in the People's Republic is not unambiguous, and causes numerous difficulties, from the historical perspective. The organisation and functioning of special education of the time, were accompanied by continuous tensions in politics, and by the financial difficulties of the state, which directly resulted in the material and organisational base of this type of education. There is no doubt, that the educational model functioning at the time, based solely on special schools, often departed from the Western European experiences and models, however, it was presented as a model, among the socialist countries.

Following 1989, special education was subject to gradual modification, in the spirit of integration, adopted in the western world. The geopolitical changes of the 1990s, caused the current educational model (mixed model) to form, based, i.a. on the activity of pre- 
schools, school-educational centres, and integrated classes, as well as, particularly in the last couple of years, on inclusion.

It is worth mentioning, that the "Report on the state and the directions of the development of national education in the Polish People's Republic” („Raport o stanie i kierunkach rozwoju edukacji narodowej w warunkach Polskiej Rzeczypospolitej Ludowej"), prepared already in 1989, by the Expert Committee for National Education, contained numerous valuable information regarding special education, which - while it might be too optimistic - was evaluated as "going in the right direction". The greatest ailment of the PRL educational system was associated with the unsatisfactory pace of building special schools. At the turn of the 1980s, the education of additional pedagogical staff, and the need for systemic actions for comprehensive counselling, and disability diagnostics, were considered to be essential ${ }^{59}$.

In the contemporary model of special education in Poland, there is a search for the optimised solutions that would allow for a subjectification of persons with disabilities, in regard to social aid, education, employment and ensuring to meet all their existential needs a thing that was long awaited, and was once impossible to achieve. The accomplishment of such tasks is multi-aspect and, despite the indisputable achievements, often faces numerous obstacles, i.a. of administrative and legislative nature, and is a result of various types of barriers of social nature ${ }^{60}$.

${ }^{59}$ Edukacja Narodowym Priorytetem. Raport o stanie i kierunkach rozwoju edukacji narodowej w Polskiej Rzeczypospolitej Ludowej, Warszawa - Kraków 1989; Cz. Kupisiewicz (ed.), Drogi i bezdroża polskiej oświaty w latach 1945-2005, Warszawa 2005.

60 See: J. Pańczyk (ed.), Tożsamość polskiej pedagogiki specjalnej u progu XXI w. Materiały z konferencji zorganizowanej z okazji Jubileuszu 75-lecia WSPS w dniach 7-8.05.1997 r., Wyd. WSPS, Warszawa 1998; B. Marcinkowska, Kształcenie uczniów z niepetnosprawnościa w Polsce - przeszłość, teraźniejszość, przyszłość, „Psychologia Wychowawcza", no 7, 2005; W. Dykcik, A. Twardowski (eds.), Poznańska pedagogika specjalna, Wyd. UAM. Poznań 2006; S. Lorek, Integracja dzieci niepetnosprawnych ze zdrowymi rówieśnikami - wartościowe partnerstwo, „Nauczyciel i Szkoła”, no 3-4, 2009, pp. 35-41; G. Szumski, Integracyjne kształcenie niepetnosprawnych, PWN, Warszawa 2009; A. Krause, Człowiek niepetnosprawny wobec przeobrażeń społecznych, Oficyna 
After 1989, the ideas of integrated education gained the approval of the teachers and the society. An exemplification of this, was the 1993 "Government programme of actions for persons with disabilities, and their integration with the society" ("Rzadowy program dziatan na rzecz osób niepetnosprawnych $i$ ich integracji ze społeczeństwem"), and numerous social campaigns, referring to the spirit of these changes.

The rights of persons with disabilities were legally ensured in the Polish constitution of 1997, and in the "Act on the vocational and social rehabilitation, and the employment of persons with disabilities" („O rehabilitacji zawodowej $i$ społecznej oraz zatrudnieniu osób niepetnosprawnych" - 1997) ${ }^{61}$, as well as, in a number of detailed directives issued by the Ministry of National Education ${ }^{62}$.

The reality of special education after 1989/1990, have gone through thorough transformations, and were directly related to the forming of a new civil society. For almost three decades, the enormous role in this matter has been played - apart from institutional activity - by third-sector organisations, based on the activity of the people of good will, who are concerned with the fate of the persons with disabilities. Historically looking, in this aspect, the quote from Maria Grzegorzewska, that "Everything everywhere means man"

Wydawnicza „Impuls”, Kraków 2004; Eadem, Współczesne paradygmaty pedagogiki specjalnej, Oficyna Wydawnicza „Impuls”, Kraków 2011; I. Chrzanowska, Pedagogika specjalna: od tradycji do wspótczesności, Oficyna Wydawnicza „Impuls”, Kraków 2018; J. Głodkowska, K. Sipowicz, I. Patejuk-Mazurek, Tradycja i wspótczesność pedagogiki specjalnej w tworzeniu społeczeństwa dla wszystkich. W 95-lecie Akademii Pedagogiki Specjalnej im. Marii Grzegorzewskiej, Warszawa, Wyd. APS, 2018.

61 RP Law Gazette, 1997, no 123, pos. 776 / 27 August 1997 Act on the vocational and social rehabilitation and the employment of persons with disabilities/; Law Gazette, 1997, no 78, pos. 483 /The Constitution of Poland - 2 April 1997/.

62 For example: the directives and resolutions regarding: the organisation and the principles of the operations of psychological-pedagogical counselling, from 1993, regarding the principle of organising care for students with disabilities, their education in mainstream and integrated public preschools, schools, and institutions, as well as, the organisation of special education, 4 October 1993; regarding the types, organisations, and the principles of operations of public care-educational, and resocialisation instiutions, 21 February 1994. 
is, and will always be up to date. It seems, that despite the changing reality, it is the human factor, and not just appropriate legal and administrative factors, have always been, and is now, the main resource that decides on the quality of the special education system quality in Poland 63 .

\section{Bibliography}

Monographs and articles

[1] Balcerek M., Rozwój szkolnictwa specjalnego i opieki nad dzieckiem w Polsce okresu międzywojennego, „Rozprawy z Dziejów Oświaty”, vol. 12, 1969, pp. 143-225.

[2] Bendych E., Powstanie i rozwój tyflopedagogiki w Polsce, [in:] U. Eckert, K. Poznański (ed.), Pedagogiki specjalna w Polsce, Wyd. WSPS, Warszawa 1992, pp. 127-133.

[3] Bilikiewicz T., Gallus J., Psychiatria polska na tle dziejowym, Warszawa 1962.

[4] Borzyszkowska H., Oligofrenopedagogika, Kraków 1998.

[5] Chrzanowska I., Pedagogika specjalna: od tradycji do wspótczesności, Oficyna Wydawnicza „Impuls”, Kraków 2018.

[6] Doroszewski W., Sprawy terminologiczne, „Szkoła Specjalna”, no 1, 1969, pp. 1-4.

[7] Dykcik W., Twardowski A. (ed.), Poznańska pedagogika specjalna, Wyd. UAM. Poznań 2006.

[8] Grodecka E., Historia niewidomych polskich w zarysie, Warszawa 1996.

[9] Gasik W., Rozwój praktyki i teorii pedagogiki specjalnej w XIX i początkach XX w., [in:] S. Mauersberg (red), Dzieje szkolnictwa i pedagogiki specjalnej, Warszawa 1990.

[10] Gasik W., Szkolnictwo specjalne w latach wojny i okupacji (1939-1945), [in:] S. Mauersberg (ed.), Dzieje szkolnictwa i pedagogiki specjalnej, Warszawa 1990, pp. 240-247.

[11] Georgens J.D., Deinhardt H.M., Pedagogika lecznicza (ortopedagogika) ze szczególnym uwzględnieniem idiotyzmu i zakładów dla idiotów, 1861.

[12] Giryński A., Rozwój szkolnictwa specjalnego dla osób upośledzonych umystowo w Polsce, ,Roczniki Pedagogiki Specjalnej”, vol. 8, 1997, pp. 9-15.

[13] Głodkowska J., Sipowicz K., Patejuk-Mazurek I., Tradycja i wspótczesność pedagogiki specjalnej w tworzeniu społeczeństwa dla wszystkich. W 95-lecie Akademii Pedagogiki Specjalnej im. Marii Grzegorzewskiej, Warszawa, Wyd. APS, 2018.

${ }^{63}$ M. Grzegorzewska, Listy do młodego nauczyciela, cykl. I-III, Wyd. WSPS, Warszawa 2002. 
[14] Grzegorzewska M., Listy do młodego nauczyciela, cykl. I-III, Wyd. WSPS, Warszawa 2002.

[15] Grzegorzewska M., Losy wojenne i odbudowa Państwowego Instytutu Pedagogiki Specjalnej, „Szkoła Specjalna”, no 1, 1946/47, pp. 6-12.

[16] Grzegorzewska M., Państwowy Instytut Pedagogiki Specjalnej w Warszawie, "Szkoła Specjalna”, no 1, 1924.

[17] Grzegorzewska M., Skrypt wykładów w Państwowym Instytucie Pedagogiki Specjalnej, Warszawa 1960.

[18] Grzegorzewska M., Szkolnictwo specjalne, [in:] S. Łempicki, W. Gottlieb, B. Suchodolski, J. Włodarski (eds.), Encyklopedia wychowania, vol. 3, cahier 1, Warszawa 1937-1939.

[19] Heller T., Grundriss der Heilpädagogik, 1904 (Polish translation: Podstawowy zarys pedagogiki leczniczej, Warszawa 1905).

[20] Heller T., Studiem zur Blindenpsychologie, 1895

[21] Hulek A., Pedagogika rewalidacyjna, Warszawa 1980

[22] Hulek A., Stan obecny i kierunki przebudowy ksztatcenia specjalnego w Polsce, PWN, 1989.

[23] Jamrożek W., Kongresy i zjazdy pedagogiczne w rozwoju polskiej myśli i praktyki edukacyjnej (do 1939 roku), Poznań 2015.

[24] Kalinowski M., Pełka M., Zarys dziejów resocjalizacji nieletnich, Warszawa 2003.

[25] Karpińska L., Zarys dziejów warszawskiego Instytutu Głuchoniemych i Ociemniatych w latach 1817-1917, [in:] O. Lipkowski (ed.), O wychowaniu dzieci gtuchych. W150 lecie Instytutu Gtuchoniemych i Ociemniatych w Warszawie, Warszawa 1967.

[26] Kirejczyk K., Ewolucja systemów dzieci głuchych, Warszawa 1967

[27] Krause A., Człowiek niepetnosprawny wobec przeobrażeń społecznych, Oficyna Wydawnicza „Impuls”, Kraków 2004;

[28] Krause A., Wspótczesne paradygmaty pedagogiki specjalnej, Oficyna Wydawnicza „Impuls”, Kraków 2011.

[29] Kuczyńska-Kwapisz J., Dzieje kształcenia niewidomych na ziemiach polskich i perspektywy rozwoju wspótczesnej tyflopedagogiki, „Roczniki Pedagogiki Specjalnej”, vol. 8, 1997, pp. 43-57.

[30] Kulbaka J., Szkolnictwo specjalne w polityce w polityce społeczno-oświatowej państwa w latach 1944-1948, „Przegląd Historyczno-Oświatowy”, no 3-4, 2005.

[31] Kulbaka J., Szkolnictwo specjalne w Polsce w pracach Ministerstwa Oświaty w latach 1956-1961, „Przegląd Historyczno-Oświatowy”, no 1-2, 2009.

[32] Kulbaka J., Szkolnictwo specjalne w pracach ministerstwa oświaty w okresie przygotowań $i$ realizacji planu sześcioletniego (1950-1955), „Przegląd HistorycznoOświatowy", no 1-2, 2007.

[33] Kupisiewicz Cz. (ed.), Drogi i bezdroża polskiej oświaty w latach 1945-2005, Warszawa 2005.

[34] Kupisiewicz Cz. (ed.), Drogi i bezdroża polskiej oświaty w latach 1945-2005, Warszawa 2005. 
[35] Lipkowski O., Poczatki szkolnictwa specjalnego, [in:] Ł. Kurdybacha (ed.), Historia wychowania, vol. 2, PWN, 1968, pp. 206-212.

[36] Lipkowski O., Wychowanie dzieci społecznie niedostosowanych, Warszawa 1966.

[37] Lorek S., Integracja dzieci niepetnosprawnych ze zdrowymi rówieśnikami - wartościowe partnerstwo, „Nauczyciel i Szkoła”, no 3-4, 2009, pp. 35-41.

[38] M. Balcerek, Rozwój wychowania i kształcenia dzieci upośledzonych. Zarys historyczny, Warszawa 1981.

[39] Madajczyk Cz., Polityka okupanta wobec narodu polskiego, Warszawa 1961; A. Götz, Obciążeni. Eutanazja w nazistowskich Niemczech, Wyd. Czarne, Wołowiec 2015.

[40] Manczarski A., Historia nauczania głuchoniemych, „Nauczyciel Głuchoniemych i Ociemniałych", no 2-3, 1934.

[41] Marcinkowska B., Kształcenie uczniów z niepetnosprawnościa w Polsce - przeszłość, teraźniejszość, przyszłość, „Psychologia Wychowawcza”, no 7, 2005.

[42] Mauersberg S. (ed.), Dzieje szkolnictwa i pedagogiki specjalnej, Warszawa 1990.

[43] Mauersberg S., Opieka nad dzieckiem i szkolnictwo specjalne, [in:] Historia wychowania wiek XX, (ed.) J. Miąso, vol. 1, PWN, Warszawa 1980, pp. 105-111.

[44] Michalski S., Praca naukowo-badawcza nauczycieli w Drugiej Rzeczypospolitej, Wyd. UAM, Poznań 1994.

[45] Nowakowski J., Drogi przebudowy szkolnictwa specjalnego, "Szkoła Specjalna”, no 3, 1965.

[46] Nurowski E., Pedagogika specjalna w szkolnictwie powszechnym, WSiP, Warszawa 1991.

[47] Nurowski E., Surdopedagogika polska. Zarys historyczny, Warszawa 1983.

[48] Pańczyk J. (ed.), Tożsamość polskiej pedagogiki specjalnej u progu XXI w. Materiały $\mathrm{z}$ konferencji zorganizowanej $\mathrm{z}$ okazji Jubileuszu 75-lecia WSPS $\mathrm{w}$ dniach 7-8.05.1997 r., Wyd. WSPS, Warszawa 1998.

[49] Pękowska M., Lwowskie zakłady dla głuchych i niewidomych dzieci w latach 1830-1914, Kielce 2003.

[50] Rachoński M., Aktualne problemy kształcenia zawodowego młodzieży upośledzonej umystowo, [in:] Wychowanie dzieci upośledzonych umystowo. Sekcja Szkolnictwa Specjalnego, Warszawa 1960, pp. 62-81.

[51] Ryll H., Stan szkolnictwa specjalnego w ostatnim piętnastoleciu, „Szkoła Specjalna”, no 1-2, 1938/39, pp. 147-157.

[52] Sękowska Z., Wprowadzenie do pedagogiki specjalnej, Warszawa 1998.

[53] Speck O., Niepetnosprawni w społeczeństwie. Podstawy ortopedagogiki, Gdańsk 2005.

[54] Szczepankowski B., Niestyszący - Gtusi - Gtuchoniemi, Warszawa 1999.

[55] Szumski G., Integracyjne kształcenie niepetnosprawnych, PWN, Warszawa 2009.

[56] Wałaszewski K., Tysiąc szkót na Tysiąclecie: Szkoty Tysiąclecia - architektura, propaganda, polityka, Łódź 2018. 
[57] Winiarz A., Szkolnictwo Księstwa Warszawskiego i Królestwa Polskiego (1807-1831), Lublin 2002.

[58] Wyczesany J., Pedagogika upośledzonych umystowo, Kraków 2007.

[59] Zaorska M., Rehabilitacja i edukacja osób z niepetnosprawnościa sprzężona w kontekście historycznym i stan aktualny, [in:] J. Błeszyński, D. Baczała, J. Binnebesel (eds.), Osoba z niepetnosprawnością - opieka - terapia-wsparcie, Łódź 2008, pp. 79-104.

Printed and non-printed sources

[1] Archive of the Ministry of National Education, Catalogue A., sign.: 538/4 (regarding the school inspections in each school board, reports, and budget issus); $476 / 2$ (information regarding the network and organisation of special education); 133/2 (budget plans for 1969 and 1970).

[2] Sejm Library, The Committee of Education Press Newsletter, no 40, 1970, 94, 1972, 97, 1972 (PRL Sejm, VI term); sign. 323/VII (PRL Sejm, VII term).

[3] The Archive of the Ministry of National Education in Warsaw Archive, Catalogue A., sign.: 177, 180, 258, 270, 280, 376.

[4] Sejm Library, The Index for Stenographic Reports from the PRL Sejm for VIII term (1980-1985).

[5] Sejm Library: The Index for Stenographic Reports from the PRL Sejm for III term (1961-1965) and for IV term (1965-1969).

[6] The instruction regarding the organisation of the 1951/1952 school year for special education (Official Gazette of the Ministry of Education, no 7, item 78, 1951).

[7] The 1952/1953 school year instruction (Official Gazette of the Ministry of Education, no 6 , item 48, 1952).

[8] The directive regarding the operation of the county selection committees for children with hearing and speech impairment (Official Gazette of the Ministry of Education, no 4, item 49, 1960).

[9] Official Gazette of the Ministry of National Education, no 67, pos. 322, 1993 (a directive regarding the organisation of psychological-pedagogical units).

[10] The 23 March 1956 decree on compulsory special education (Law gazette, 1956, no 9 , pos. 52).

[11] RP Law Gazette, 1997, no 123, pos. 776 (27 August 1997 Act on the vocational and social rehabilitation and the employment of persons with disabilities).

[12] Law gazette, 1976, no 15, pos. 93 (The 2 April 1976 edict by the Council of Ministers regarding the creation of Maria Grzegorzewska University).

[13] Law Gazette, 1997, no 78, pos. 483 (The Constitution of Poland - 2 April 1997).

[14] Edukacja Narodowym Priorytetem. Raport o stanie i kierunkach rozwoju edukacji narodowej w Polskiej Rzeczypospolitej Ludowej, Warszawa - Kraków 1989. 
[15] GUS, Polska w liczbach, 1962, p. 67.

[16] 1921 March Constitution (Law Gazette, no 44, pos. 267).

[17] O szkotę polską. Pierwszy Ogólnopolski Wielki Zjazd Nauczycielski 14, 15, 16 i 17 kwietnia w Warszawie, Lwów - Warszawa 1919.

[18] The report from the II Polish Special School Teachers Convention, "Szkoła Specjalna", vol. XI, no 2, 3, 4.

[19] March 1932 School Act of Janusz Jędrzejewicz (Law Gazette of the Polish Republic, 1932, no 38, pos. 389).

[20] Ustawa o rozwoju systemu oświaty i wychowania w Polsce Ludowej, Warszawa 1961.

[21] Założenia programowo-organizacyjne $w$ dziesięcioletnich szkołach specjalnych, Warszawa 1977.

[22] The directive regarding special classes, by the Ministry of Education (see: Official Gazette of the Ministry of Education, 1961, no 12, pos. 159). 